\title{
The Immobilisation of Heavy Metals from Sewage Sludge Ash in $\mathrm{CO}_{2}$-Cured Mortars
}

\author{
Erick Grünhäuser Soares ${ }^{1, * \mathbb{D}}$, João Castro-Gomes ${ }^{1} \mathbb{D}$, Mateusz Sitarz ${ }^{2} \mathbb{D}$, Tomasz Zdeb ${ }^{2}$ and Izabela Hager $^{2} \mathbb{D}$ \\ 1 Centre of Materials and Building Technologies (C-MADE), \\ Department of Civil Engineering and Architecture, University of Beira Interior (UBI), \\ 6201-001 Covilhã, Portugal; jpcg@ubi.pt \\ 2 Faculty of Civil Engineering, Cracow University of Technology, 31-155 Cracow, Poland; \\ mateusz.sitarz@pk.edu.pl (M.S.); tomasz.zdeb@pk.edu.pl (T.Z.); izabela.hager@pk.edu.pl (I.H.) \\ * Correspondence: e.grunhauser@ubi.pt
}

Citation: Grünhäuser Soares, E.; Castro-Gomes, J.; Sitarz, M.; Zdeb, T.; Hager, I. The Immobilisation of Heavy Metals from Sewage Sludge Ash in $\mathrm{CO}_{2}$-Cured Mortars. Sustainability 2021, 13, 12893. https:// doi.org/10.3390/su132212893

Academic Editor: Franco Ajmone Marsan

Received: 21 October 2021 Accepted: 17 November 2021 Published: 22 November 2021

Publisher's Note: MDPI stays neutral with regard to jurisdictional claims in published maps and institutional affiliations.

Copyright: (C) 2021 by the authors. Licensee MDPI, Basel, Switzerland. This article is an open access article distributed under the terms and conditions of the Creative Commons Attribution (CC BY) license (https:// creativecommons.org/licenses/by/ $4.0 /)$.

\begin{abstract}
Sewage treatment processes are a serious environmental threat due to the difficulties involved in its waste management and disposal. Therefore, one developing trend in sewage sludge processing is its thermal treatment, which generates sewage sludge ash that may contain many environmental pollutants, such as heavy metals. Moreover, due to the European Union requirements that not only focus on the waste generation reduction but also on its reuse and final disposal, it is essential to pursue new applications of such resources, such as the waste-based material incorporation into alternative cementitious materials. Thus, this study evaluated the heavy metals leachability of $\mathrm{CO}_{2}$-cured mortars incorporating sewage sludge ash as filler. For this purpose, Portland cement, reactive magnesia, and electric arc furnace slag were used to produce three different $\mathrm{CO}_{2}$-cured mortars, which were cured though pressurised accelerated carbonation curing for $24 \mathrm{~h}$. These mortars presented up to $12.7 \mathrm{MPa}$ as compressive strength and their carbonation was confirmed by TG-DTG and FT-IR analyses. Their leachability of heavy metals met the European requirements for all waste materials, including inert materials, and post-industrial wastewater. Therefore, the immobilisation of heavy metals in this binding technology may be considered an effective method to safely manage sewage sludge ash.
\end{abstract}

Keywords: $\mathrm{CO}_{2}$-cured mortar; $\mathrm{CO}_{2}$ adsorption; heavy metal immobilisation; leaching; sewage sludge ash; electric arc furnace slag; carbonated reactive magnesia cement; Portland cement

\section{Introduction}

The construction materials industry, which was once based on a wide range of materials appropriate to local conditions and/or to specific needs, has evolved into an industry based on Portland cement-based materials [1]. Such a change of trend has turned Portland cement-based materials into the most heavily consumed manufactured material in the world in terms of volume, being responsible for about $7 \%$ of the total anthropogenic emissions of carbon dioxide $\left(\mathrm{CO}_{2}\right)$ [2]. Thus, worldwide concerns about $\mathrm{CO}_{2}$ emissions have increased interest in alternative binding technologies and materials to Portland cement (PC) [3,4], such as carbonated-based materials [4], mainly due to their capacity to capture and store $\mathrm{CO}_{2}$ in their matrices [5]. It has been shown to be feasible to produce $\mathrm{CO}_{2}$-cured binders with high strength results from electric arc furnace slag (EAF slag)-, PC- [6], and carbonated reactive magnesia cement (CRMC)-based materials [7], especially if the accelerated carbonation curing conditions are controlled [6] as well as the mixture designs [7]. It was also shown to be practicable to use waste materials in CRMC-based materials [8-12] which may reduce the environmental impacts and production cost of the designed materials [13].

In addition to that, the ash produced by the thermal transformation of sewage sludge is a raw material that may also be used in the production of construction binders, allowing 
cement consumption to be reduced. Due to its properties, the waste sludge generated in sewage treatment processes is a serious environmental threat. This is because of the difficulties involved in its management and disposal. One developing trend in sludge processing is thermal treatment. The basic chemical composition of sewage sludge ash (SSA) includes oxides of silicon, calcium, phosphorus, and aluminium. The amounts of individual components vary strongly depending on the region, degree of urbanisation, and the method of sewage treatment [14]. Moreover, SSA also holds heavy metals, the amount of which primarily depends on the type of sewage supplied to the treatment plant. Data available in the literature show heavy metal content in $\mathrm{mg} / \mathrm{kg}$ dry weight of sludge or ash. Unfortunately, the qualitative range of the elements in question is variable, resulting in a difficult comparative analysis. From the available literature, it is possible to undertake a basic analysis of the heavy metal content of ash from laboratory-scale combustion in an electric furnace and industrial-scale combustion in a fluidised bed furnace. Copper and zinc are found in the highest amounts regardless of the region or method of generating the ash. The elements most commonly reported in the literature are also cadmium, chromium, nickel, and lead. The content of heavy metals varies widely, regardless of how the ash was obtained [15-17].

Therefore, heavy metals should be appropriately stabilised and disposed of due to their very high toxicity levels. One method is to immobilise them-this involves initiating physical and chemical processes leading to their permanent inactivation and neutralisation. Some construction materials can act as a "matrix" and demonstrate the ability to immobilise heavy metal ions [18,19], as was recently demonstrated in geopolymer-based sewage sludge ash (SSA) mortars [20]. However, such materials may include, but are not limited to, cementitious binders $[18,19]$.

Thus, in this study, accelerated carbonation curing technology was employed to produce $\mathrm{CO}_{2}$-cured mortars incorporating SSA with the aim of developing mortars with a reduced carbon footprint and heavy metal immobilisation properties. Therefore, this study analyses the degree of immobilisation of heavy metals in SSA-based $\mathrm{CO}_{2}$-cured mortars, evaluates the compressive strength of the thus-designed mortars, and through thermogravimetry and derivative thermogravimetry (TG-DTG) and Fourier transform infrared spectroscopy (FT-IR) analyses provides pieces of evidence of the carbonation throughout the specimen's volume.

\section{Materials and Methods}

\subsection{Materials}

Sewage sludge ash (SSA) used as a filler in the $\mathrm{CO}_{2}$-cured mortars was obtained from the sewage treatment plant in Płaszów in Krakow, Poland, which is a result of the combustion of sewage sludge at a temperature of around $800{ }^{\circ} \mathrm{C}$ in a fluidised bed furnace.

The $\mathrm{CO}_{2}$-reactive compounds consist of Portland cement (PC) containing a limestone additive provided by Secil under the trade name CEM II/B-L 32.5N and reactive magnesium oxide ( $\mathrm{r}-\mathrm{MgO})$, known under the trade name "Magal $\mathrm{P}^{\prime}$, provided by Invivo-nSA, which is, in fact, calcinated magnesia mainly used as an additive to animal feed. Before being used, the $\mathrm{r}-\mathrm{MgO}$ material received was ground in a ball mill grinder and sieved to obtain particles with a diameter of less than $125 \mu \mathrm{m}$. Also included was electric arc furnace slag (EAFS) obtained from the national steel industry, located at Maia and Aldeia de Paio Pires, Seixal, Portugal. Before being used, the EAFS material received was dried in an oven at $60{ }^{\circ} \mathrm{C}$; afterwards it was ground in a ball mill grinder and subsequently sieved to obtain particles with a diameter of less than $45 \mu \mathrm{m}$. These particle sizes were used following previous research works $[6,11,12]$, in which $\mathrm{CO}_{2}$-cured binders were produced.

River sand (RS) used as fine aggregate was provided by Tabal-Sepor Areias e Argamassas LDA, which was obtained from screening natural materials from river dredging.

The estimated oxide compositions of SSA, PC, r-MgO, and EAFS, were determined by energy-dispersive X-ray spectroscopy (SEM-EDX) tests on a Hitachi S-3400N apparatus in which three different locations were randomly selected in each raw material sample to 
obtain their chemical compositions. The true powder densities of SSA, PC, r-MgO, and EAFS were determined using a gas displacement pycnometer on a Micromeritics AccuPyc 1340 apparatus. In addition, loss on ignition (LOI) of the raw materials was obtained by TG-DTG analysis, which was carried out on an SDT Q-50 (TA Instrument). These are presented in Table 1.

Table 1. Oxide composition (\% wt.) and physical properties of the raw materials.

\begin{tabular}{|c|c|c|c|c|}
\hline \multirow{2}{*}{ Oxide Composition (\% wt.) and Physical Properties } & \multicolumn{4}{|c|}{ Material } \\
\hline & SSA & PC & r-MgO & EAFS \\
\hline $\mathrm{Na}_{2} \mathrm{O}$ & 0.8 & & 0.5 & \\
\hline $\mathrm{MgO}$ & 3.6 & 2.1 & 87.2 & 4.1 \\
\hline $\mathrm{Al}_{2} \mathrm{O}_{3}$ & 10.3 & 2.8 & 1.2 & 12.0 \\
\hline $\mathrm{SiO} 2$ & 28.9 & 11.1 & 3.4 & 13.9 \\
\hline $\mathrm{P}_{2} \mathrm{O}_{5}$ & 18.4 & & & \\
\hline $\mathrm{SO}_{3}$ & 1.7 & 3.5 & & \\
\hline $\mathrm{K}_{2} \mathrm{O}$ & 2.0 & & & \\
\hline $\mathrm{CaO}$ & 14.9 & 78.0 & 4.4 & 34.2 \\
\hline $\mathrm{TiO}_{2}$ & 1.2 & & & \\
\hline $\mathrm{Cr}_{2} \mathrm{O}_{3}$ & & & & 2.7 \\
\hline $\mathrm{MnO}$ & & & & 4.0 \\
\hline $\mathrm{Fe}_{2} \mathrm{O}_{3}$ & 17.2 & 2.6 & 3.3 & 29.1 \\
\hline $\mathrm{ZnO}$ & 0.9 & & & \\
\hline Loss on ignition (\%) & 2.5 & 11.2 & 2.7 & 0.9 \\
\hline True density $\left(\mathrm{g} / \mathrm{cm}^{3}\right)$ & 2.9 & 3.0 & 3.5 & 3.8 \\
\hline Powder appearance & & & & \\
\hline
\end{tabular}

\subsection{Mix Compositions}

The mix compositions of the $\mathrm{CO}_{2}$-cured mortars proposed in this study are detailed in Table 2. The mixtures were designed with a volume proportion of 3 to 1 , three parts of $\mathrm{RS}$ to one part of SSA binder. Reactive compounds, i.e., PC, $\mathrm{r}-\mathrm{MgO}$, and EAFS, were kept constant at $10 \%$ of the overall solid mass. The water to solid $(\mathrm{w} / \mathrm{s})$ ratios adopted were 0.10 for the PC and EAFS mix designs [6] and 0.15 for the r-MgO mix design due to their carbonation curing behaviour, since HMCs contain water in their composition whereas calcium carbonates do not, and due to preliminary experimental trials that presented dry and uncarbonated core in SSA.M when $\mathrm{w} / \mathrm{s}$ ratio of 0.10 was used.

Table 2. Mix compositions.

\begin{tabular}{|c|c|c|c|c|c|c|c|}
\hline \multirow{2}{*}{\multicolumn{2}{|c|}{ Raw Material }} & \multicolumn{2}{|c|}{ SSA.P } & \multicolumn{2}{|c|}{ SSA.M } & \multicolumn{2}{|c|}{ SSA.E } \\
\hline & & Mass (\%) & Volume (\%) & Mass (\%) & Volume (\%) & Mass (\%) & Volume (\%) \\
\hline \multirow{2}{*}{$\begin{array}{l}\text { Reactive } \\
\text { compound }\end{array}$} & $\begin{array}{c}\mathrm{PC} \\
\mathrm{r}-\mathrm{MoO}\end{array}$ & 10.0 & 9.0 & 100 & 80 & & \\
\hline & EAFS & & & & & 10.0 & 7.2 \\
\hline \multicolumn{2}{|c|}{ SSA } & 16.9 & 16.0 & 17.7 & 17.0 & 18.1 & 17.5 \\
\hline \multirow{2}{*}{\multicolumn{2}{|c|}{ RS }} & 73.1 & 75.0 & 72.3 & 75.0 & 71.9 & 75.0 \\
\hline & $\mathrm{w} / \mathrm{s}$ & 0.10 & & 0.10 & & 0.10 & \\
\hline
\end{tabular}

\subsection{Specimens' Preparation}

The specimen preparation procedure of each mix was divided into three main steps, i.e., mortar preparation, casting of specimens, and accelerated carbonation curing. To prepare the mortar, the solid materials in the planned mix compositions were mechanically blended until the mixture was homogeneous and soon afterwards, tap water was gradually added at the defined $\mathrm{w} / \mathrm{s}$ ratio resulting in a uniform mortar. To cast the specimens, the prepared mortar was placed in a prismatic mould to be compacted into a cubic format 
of edges of $40 \mathrm{~mm}$ using a static compaction pressure of $30 \mathrm{MPa}$. Once the pressure reached $30 \mathrm{MPa}$, it was maintained for more 60 seconds in order to provide a better particle adjustment to the specimens. Afterwards, the moulded specimens were extruded from the mould and placed in a moisture-saturated chamber to prevent water evaporation until three other cubes were prepared. In addition to this, during the specimen casting step, it was observed that a small quantity of water carrying fine particles was expelled. Hence, this resulted in a reduction of the water content in specimens and of fine particles.

Shortly after four specimens were cast, they were placed inside a pressurized carbonation chamber for an accelerated carbonation curing (ACC) period of $24 \mathrm{~h}$ at controlled atmosphere of $\mathrm{CO}_{2}$ concentration $>99 \%$, partial pressure of 0.7 bar, temperature of $50 \pm 2{ }^{\circ} \mathrm{C}$, and relative humidity $(\mathrm{RH})>99 \%$. Thereafter, the specimens were taken out of the carbonation chamber and were stored in room conditions (RC) for $24 \mathrm{~h}$ at a temperature of $20 \pm 2{ }^{\circ} \mathrm{C}$ and $\mathrm{RH}$ of about $60 \%$ in order to cool them down. In addition, the specimen's mass and dimensions were taken before the ACC period and after the RC period, allowing their bulk density, mass loss, and possible change of the specimen's dimensions to be determined. In addition, control specimens, SSA.P (Figure 1a), were prepared to provide a comparison with specimens that contained $\mathrm{r}-\mathrm{MgO}$ and EAFS as reactive compound, SSA.M (Figure $1 b$ ) and SSA.E (Figure 1c), respectively.

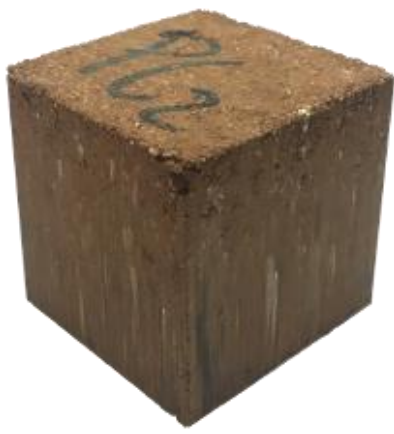

(a)

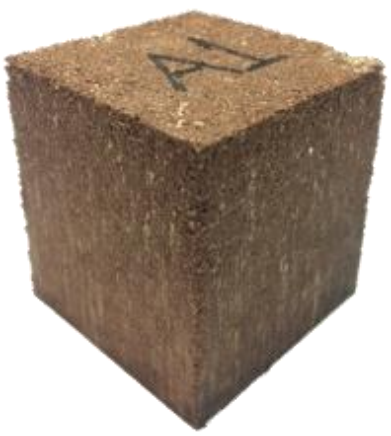

(b)

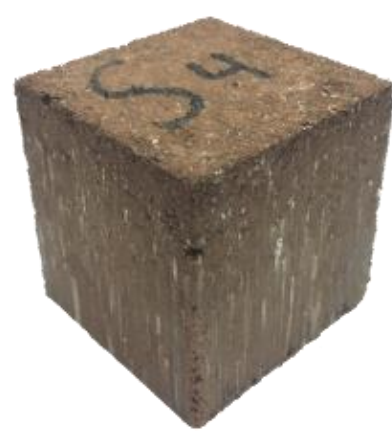

(c)

Figure 1. Specimens of (a) SSA.P, (b) SSA.M, and (c) SSA.E soon after accelerated carbonation curing.

\subsection{Compressive Strength}

Compressive strength tests were undertaken soon after the RC period had elapsed. The test was carried out on a uniaxial loading basis on three samples. The equipment used was an ADR Touch 3000 BS EN Compression Machine with digital readout and self-centring platens, operating at a constant loading rate of $2.4 \mathrm{kN} / \mathrm{s}$.

\subsection{TG-DTG}

Thermogravimetry and derivative thermogravimetry (TG-DTG) analysis of the specimens was carried out on a SDT Q-50 (TA Instrument). This was performed in the temperature range of ambient to $1000{ }^{\circ} \mathrm{C}$, at a heating rate of $20^{\circ} \mathrm{C} / \mathrm{min}$, using helium as the purge gas and platinum crucibles. The tested material consists of about $5 \mathrm{mg}$ of powdered specimen's core with a diameter of less than $63 \mu \mathrm{m}$, in order to confirm that the accelerated carbonation process took place through the whole specimen's volume.

\subsection{FT-IR}

The Fourier transform infrared spectroscopy (FT-IR) data were recorded from 600 to $4000 \mathrm{~cm}^{-1}$ using Nicolet iS10 FT-IR Spectrometer (Thermo Scientific), Smart iTR accessory instrument by diamond HATR crystal. The material used consists of particles passing throughout a $63 \mu \mathrm{m}$ aperture sieve of specimen's core. 


\subsection{Leachability of Heavy Metals}

The tests for leaching of heavy metals were conducted in accordance with the standard EN 12457-4 [21], whereby in the case of both cements and waste materials, samples reflecting their natural grain size were selected for testing. For tests of total heavy metal content, all materials were mineralised with aqua regia in the ratio of $3 \mathrm{~mL} \mathrm{HCl}+1 \mathrm{~mL}$ $\mathrm{HNO}_{3}+0.5 \mathrm{~g} \mathrm{MO}$ under closed microwave furnace conditions at $180{ }^{\circ} \mathrm{C}$ for 45 minutes. The process was carried out based on the indications of the standard PN EN 13346 [22].

Testing for heavy metal content, i.e., $\mathrm{Sb}$, As, Se, was performed by the ICP method according to PN-EN ISO 11885 [23]. For chromium, the ASA method was used according to EN 1233 [24], whereas in the case of other heavy metals, the tests were performed according to PN-ISO 8288 [25].

\section{Results and Discussion}

\subsection{Specimen Dimensions, Mass, and Bulk Density}

The results show that although every mix composition presented a loss of mass after the RC period, none presented changes in their dimensions and therefore the bulk density was reduced. The highest mass loss is ascribed to the SSA.E composite. Such behaviour seems to be an effect of free water loss due to its low hydration and carbonation rate, contrasting with the SSA.P composite. This latter presents the lowest mass loss, about $4.5 \%$, which may be related to the rapid formation of calcium carbonates. A similar mass loss to that in SSA.P was observed in the case of SSA.M specimens, where such behaviour may be related to the formation of magnesium hydroxide which partly remains uncarbonated and partly carbonates forming hydrated magnesium carbonates (HMCs) that bind the water. Therefore, the bulk density of all the prepared specimens was about $2.0 \mathrm{~g} / \mathrm{cm}^{3}$ before the ACC period, which was reduced to about 1.9 after the RC period, corresponding to a reduction of about $5 \%$, probably due to the loss of the excess of water that was not adsorbed by the cementitious matrix. The results are summarised in Table 3.

Table 3. Mass loss and bulk density of the specimens.

\begin{tabular}{cccc}
\hline \multirow{2}{*}{ Mix Design } & $\begin{array}{c}\text { Mass } \\
\text { Loss }(\%)\end{array}$ & \multicolumn{2}{c}{ Bulk Density $\left(\mathbf{g} / \mathbf{c m}^{\mathbf{3}}\right)$} \\
& Before CC & After RC \\
\hline SSA.P & 4.5 & 2.01 & 1.92 \\
SSA.M & 4.9 & 2.04 & 1.94 \\
SSA.E & 6.8 & 2.05 & 1.92 \\
\hline
\end{tabular}

\subsection{Compressive Strength}

The uniaxial compressive strength of the SSA.P, SSA.M, and SSA.E composites was 12.7, 10.9, and 4.2 MPa, respectively. The standard deviations (SD) of the compressive strength results for SSA.P and SSA.E were $0.23 \mathrm{MPa}$, while that for SSA.M was $0.65 \mathrm{MPa}$, which indicates that all the mortars show a homogenous structure and behaviour. The level of compressive strength observed was expected due to the high carbonation capability of PC, which comprises $78.0 \% \mathrm{CaO}$, and of $\mathrm{r}-\mathrm{MgO}$, which contains $87.2 \% \mathrm{MgO}$. In contrast to the previous materials, although the compressive strength of SSA.E was the lowest, the result obtained is promising since the composite is produced solely from waste materials, i.e., EAFS containing only $34.2 \% \mathrm{CaO}$ and SSA with $14.9 \% \mathrm{CaO}$. The results are shown in Figure 2. 


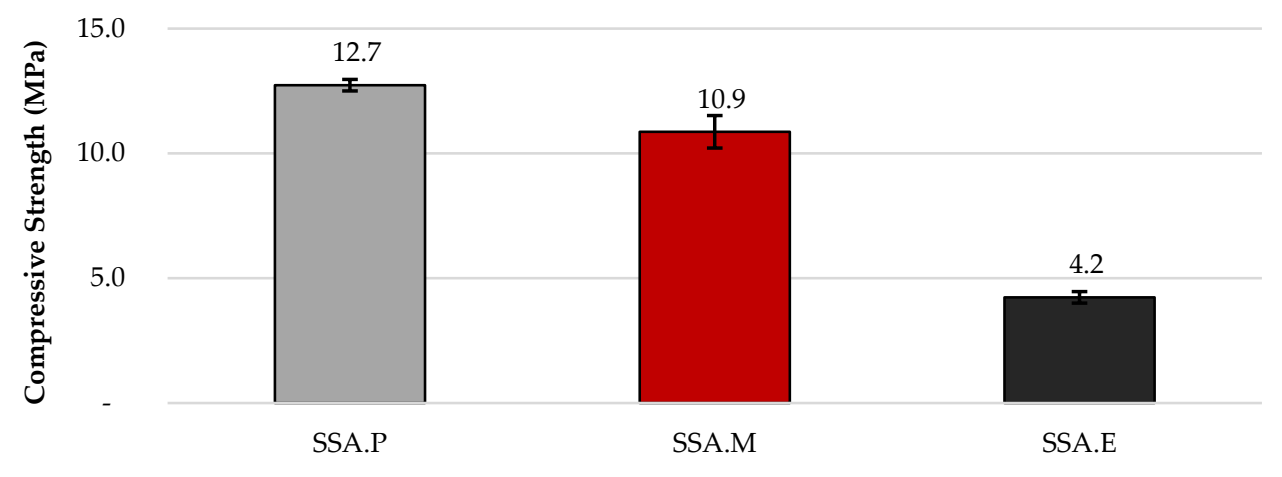

Figure 2. Compressive strength results.

\subsection{TG-DTG}

\subsubsection{Raw Materials}

The TG-DTG results (Figure 3) showed different trends for each raw material. Although all the materials presented mass loss at a temperature of $1000^{\circ} \mathrm{C}$, the EAFS presented two steps of gain in weight, the first occurred between the temperature range of about 400 to $530{ }^{\circ} \mathrm{C}$ and the second from about 650 to $900{ }^{\circ} \mathrm{C}$, probably due to the oxidation of metals [26,27].

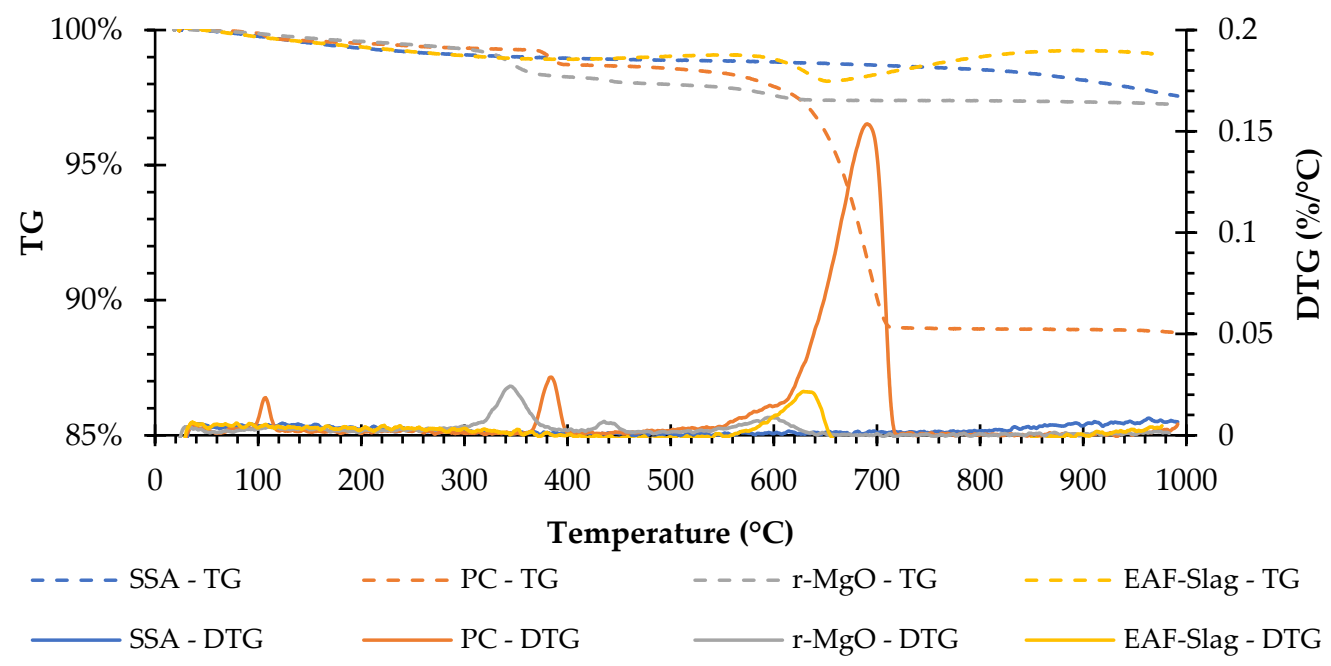

Figure 3. TG-DTG curves of the raw materials.

The SSA does not present clear peaks in DTG curves. The PC presents three welldefined peaks at about 110,390 , and $695^{\circ} \mathrm{C}$ that may be respectively related to the dehydration of the calcium sulphate dihydrate $\left(\mathrm{CaSO}_{4} \cdot 2 \mathrm{H}_{2} \mathrm{O}\right)$ [28-31], the dehydration of calcium hydroxide $\left(\mathrm{Ca}(\mathrm{OH})_{2}\right)\left(350-500{ }^{\circ} \mathrm{C}\right)[30,32]$, and the decarbonation of calcium carbonates $\left(\mathrm{CaCO}_{3}\right)\left(>500{ }^{\circ} \mathrm{C}\right)[28-30,33]$. The r-MgO presents three peaks at about 350 , 450 , and $600{ }^{\circ} \mathrm{C}$ that may be respectively related to the dehydration of brucite [34], the decarbonation of HMCs (i.e., nesquehonite and hydromagnesite) [34], and decarbonation of magnesium carbonates $\left(\mathrm{MgCO}_{3}\right)$ [35]. Finally, the EAFS presents one that seems to be related to the decarbonation of calcium carbonates $\left(\mathrm{CaCO}_{3}\right)[28-30,32]$.

\subsubsection{Mixtures Design}

The thermogravimetric measurements, i.e., TG and DTG curves in the range from ambient temperature to $1000^{\circ} \mathrm{C}$ for the SSA.P, SSA.M, and SSA.E specimens, are shown in Figure 4 . The TG curves of the SSA.P and SSA.M mortars exhibit a gradual weight loss, while SSA.E presents a weight loss up to $650{ }^{\circ} \mathrm{C}$, but presents similar behaviour to the EAFS raw material, showing a weight gain in the temperature range of 650 to $850^{\circ} \mathrm{C}$ that is also probably due to the oxidation of metals presented in EAFS [26,27]. 


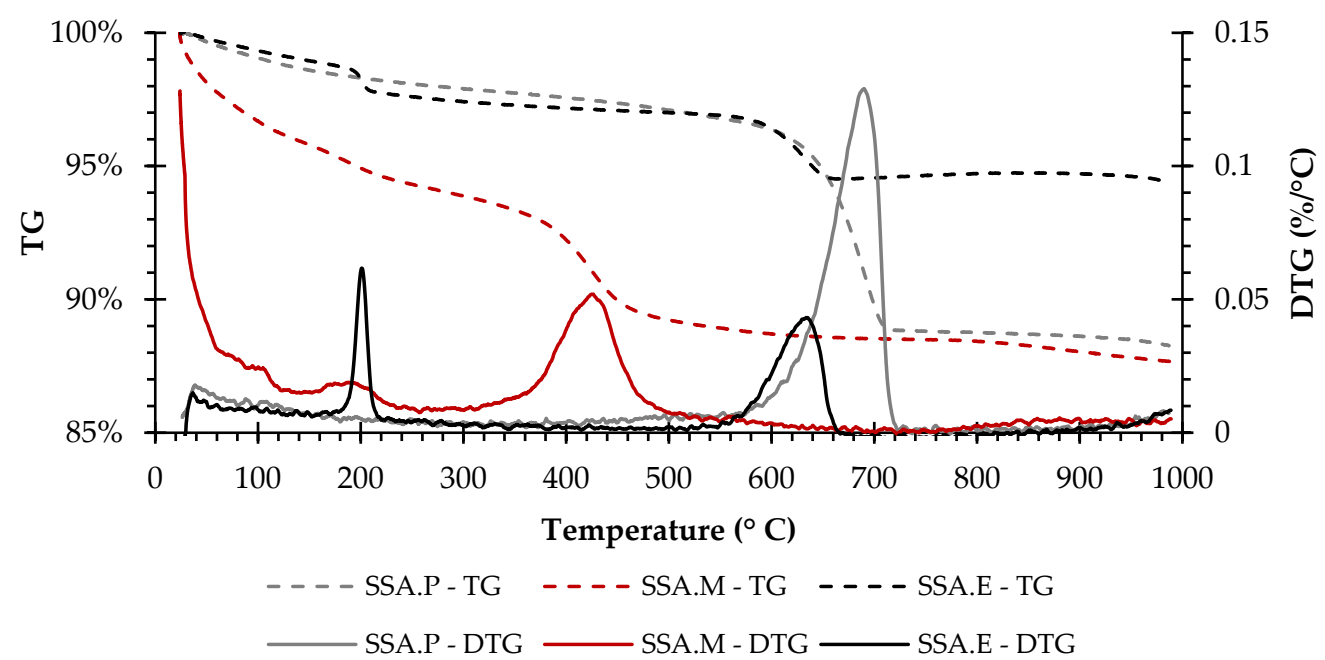

Figure 4. TG-DTG curve of SSA.P, SSA.M, and SSA.E.

Furthermore, the peak at about $690^{\circ} \mathrm{C}$ on the DTG curve of SSA.P is attributed to the decarbonation of the limestone [29,32] present as an additive in Portland cement. The first weight loss, up to about $300{ }^{\circ} \mathrm{C}$, of SSA.M may be related to the dehydration of HMCs formed, while the peak at about $425^{\circ} \mathrm{C}$ is related to the decarbonation of the HMCs [34,36] and remained uncarbonated brucite [34]. In turn, the DTG curve of SSA.E presents two peaks, the first at about $200{ }^{\circ} \mathrm{C}$ may be related to dehydration of calcium aluminate and silicoaluminate hydrates $(\mathrm{C}-\mathrm{A}-\mathrm{H}$ and $\mathrm{C}-\mathrm{A}-\mathrm{S}-\mathrm{H})[37,38]$, while the second at about $635^{\circ} \mathrm{C}$ is related to the decarbonation of calcium carbonates $\left(\mathrm{CaCO}_{3}\right)[29,32,38]$. Furthermore, the probable presence of $\mathrm{C}-\mathrm{A}-\mathrm{H}$ and $\mathrm{C}-\mathrm{A}-\mathrm{S}-\mathrm{H}$ seems be associated to the chemical composition of the SSA and EAFS and to the lower reactivity to $\mathrm{CO}_{2}$ of the latter when compared to PC.

\subsection{FT-IR}

The FT-IR spectra of the three $\mathrm{CO}_{2}$-cured mortars is exhibited in Figure 5. The transmittance bands related to accelerating carbonation curing are seen at $\sim 880 \mathrm{~cm}^{-1}$ $\left(\mathrm{CO}_{3}{ }^{2-}\right.$ bending vibrations) [39], at $\sim 1480 \mathrm{~cm}^{-1}\left(\mathrm{CO}_{3}{ }^{2-}\right.$ stretching vibration) [40] and at $\sim 2350 \mathrm{~cm}^{-1}\left(\mathrm{CO}_{2}\right.$ inclusion or a terminal $\left.\mathrm{CO}_{2}\right)$ [41]. In addition, the transmittance band at $\sim 1050 \mathrm{~cm}^{-1}$ corresponds to the asymmetric stretching vibration band of $\mathrm{Si}-\mathrm{O}-\mathrm{Si}(\mathrm{Al})$ [40]. Thus, these results, allied to the finds on TG-DTG analysis, indicate that the $\mathrm{CO}_{2}$-cured mortars experienced, at a certain point, an accelerated carbonation through their whole volume, reaching up to their core.

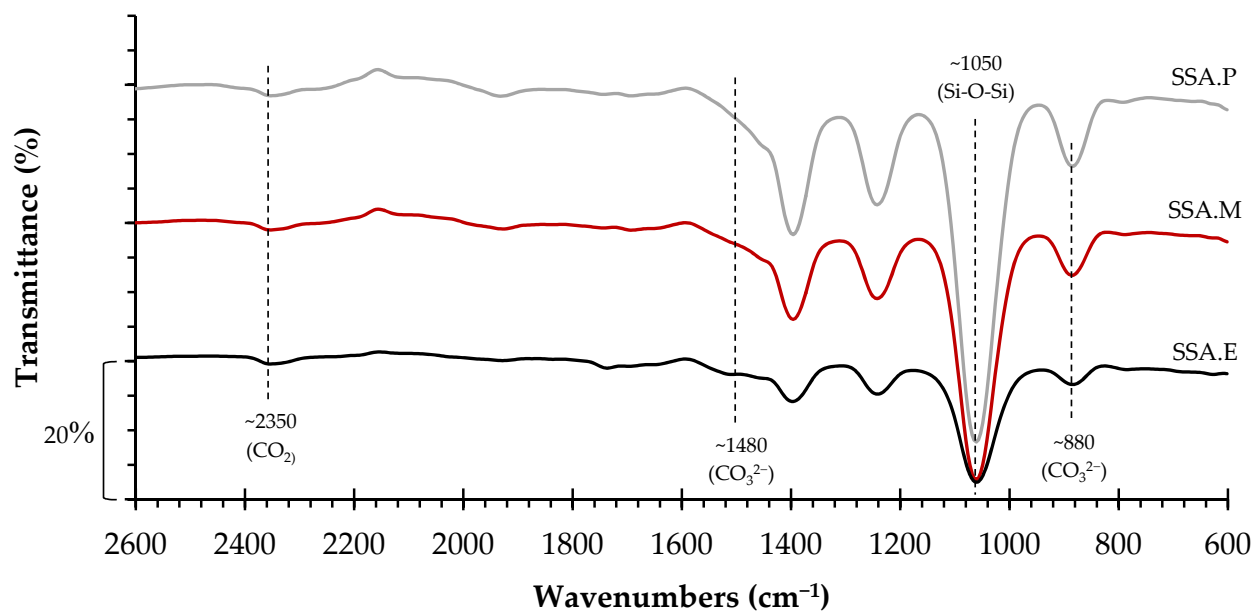

Figure 5. FT-IR curves of the $\mathrm{CO}_{2}$-cured mortars. 


\subsection{Leachability of Heavy Metals}

The total heavy metal content of the SSA ash and all mortars containing the waste material is presented in Table 4 . The leachability of heavy metals from $\mathrm{CO}_{2}$-cured mortars is collectively presented in Table 5 . Based on the information obtained, the leachability percentages were calculated for each metal (Table 6) and visualised in Figure 6. Table 7 summarises the requirements of the Polish regulations based on European directives: (i) Journal of Laws of the Republic of Poland, item 1277/1.09.2015-Regulation of the Minister of Economy of 16 July 2015 on the approval of waste for landfills [42]; (ii) Journal of Laws of the Republic of Poland, item $984 \mathrm{n}^{\circ}$. 137/2006-Regulation of the Minister of Environment of 24 July 2006 on the conditions to be met when introducing sewage to waters or to the ground, and on the substances that are particularly harmful to the aquatic environment [43]; (iii) Journal of Laws of the Republic of Poland, item 1747/29.08.2019Regulation of the Minister of Maritime Affairs and Inland Navigation of 29 August 2019 on the requirements to be met by surface waters used for supplying the population with water intended for human consumption [44]; and (iv) Journal of Laws of the Republic of Poland, item 2294/7.12.2017-Regulation of the Minister of Health of 7 December 2017 on the quality of water intended for human consumption [45].

Table 4. Total heavy metal content in SSA ash and mortars ( $\mathrm{mg} / \mathrm{kg}$ of dry weight).

\begin{tabular}{ccccc}
\hline Metal & SSA & SSA.P & SSA.M & SSA.E \\
\hline Antimony & 14 & $<4$ & $<4$ & $<4$ \\
Arsenic & 9.3 & 6.4 & 3.9 & 8.5 \\
Chromium & 446 & 50 & 101 & 507 \\
Zinc & 3532 & 670 & 511 & 723 \\
Cadmium & $<8$ & $<8$ & $<8$ & $<8$ \\
Copper & 668 & 115 & 84 & 127 \\
Nickel & 156 & $<40$ & $<40$ & 47 \\
Lead & 124 & $<40$ & $<40$ & $<40$ \\
Mercury & 0.371 & 0.257 & 0.314 & 0.442 \\
Selenium & $<2$ & $<4$ & $<4$ & $<4$ \\
\hline
\end{tabular}

Table 5. Leachability of heavy metals from SSA ash and mortars (mg/L).

\begin{tabular}{ccccc}
\hline Metal & SSA & SSA.P & SSA.M & SSA.E \\
\hline Antimony & 0.042 & $<0.02$ & $<0.02$ & $<0.02$ \\
Arsenic & 0.037 & $<0.02$ & $<0.02$ & $<0.02$ \\
Chromium & $<0.2$ & $<0.2$ & $<0.2$ & $<0.2$ \\
Zinc & $<0.08$ & $<0.08$ & $<0.08$ & $<0.08$ \\
Cadmium & $<0.04$ & $<0.04$ & $<0.04$ & $<0.04$ \\
Copper & $<0.06$ & $<0.06$ & $<0.06$ & $<0.06$ \\
Nickel & $<0.2$ & $<0.2$ & $<0.2$ & $<0.2$ \\
Lead & $<0.2$ & $<0.2$ & $<0.2$ & $<0.2$ \\
Mercury & $<0.0003$ & $<0.0004$ & $<0.0004$ & $<0.0004$ \\
Selenium & 0.3 & $<0.02$ & $<0.02$ & $<0.02$ \\
\hline
\end{tabular}

In most cases, the leachability of heavy metals, regardless of the material considered, is below detection level. This includes chromium, zinc, cadmium, copper, nickel, lead, and mercury. Therefore, the leachability of these metals in the test materials is at a level that constitutes an environmental hazard. The criteria for inert waste and sewage waste are met. In the case of antimony and arsenic, although their leachability was above the detection level, their contents are low enough that they similarly also meet all the criteria met by the previously mentioned heavy metals. In contrast, the highest level of leachability observed is for selenium from SSA ash. Relative to the total content, this amounts to $100 \%$. In this case, the requirements for inert waste were not met, while this ash meets the criteria for non-inert waste and wastewater. It is worth noting that the level of selenium leaching from 
mortars is already much lower, at only $5 \%$. In conclusion, the $\mathrm{CO}_{2}$-cured mortars with SSA content that were analysed, SSA.P, SSA.M, and SSA.E, meet the criteria for all waste materials including inert waste as well as for post-industrial wastewater as can be seen in Figure 7. Moreover, it was noticed that among the three $\mathrm{CO}_{2}$-cured mortars that the highest degree of immobilisation of the heavy metals tested was observed in the SSA.E mortar, in which this property is most visible in the case of arsenic, chromium, copper, nickel, and mercury as can be observed in Figure 6.

Table 6. Leachability of heavy metals from ash and mortars in relation to total metal content (\% wt.).

\begin{tabular}{ccccc}
\hline Metal & SSA $_{\mathbf{8 0 0}}$ & SSA.P & SSA.M & SSA.E \\
\hline Antimony & 3.02 & $<5.03$ & $<5.06$ & $<5.01$ \\
Arsenic & 4 & $<3.14$ & $<5.19$ & $<2.36$ \\
Chromium & $<0.45$ & $<4.02$ & $<2.00$ & $<0.40$ \\
Zinc & $<0.02$ & $<0.12$ & $<0.16$ & $<0.11$ \\
Cadmium & $<5.03$ & $<5.03$ & $<5.06$ & $<5.01$ \\
Copper & $<0.09$ & $<0.52$ & $<0.72$ & $<0.47$ \\
Nickel & $<1.29$ & $<5.03$ & $<5.06$ & $<4.26$ \\
Lead & $<1.62$ & $<5.03$ & $<5.06$ & $<5.01$ \\
Mercury & $<0.81$ & $<1.57$ & $<1.29$ & $<0.91$ \\
Selenium & 100 & $<5.03$ & $<5.06$ & $<5.01$ \\
\hline
\end{tabular}

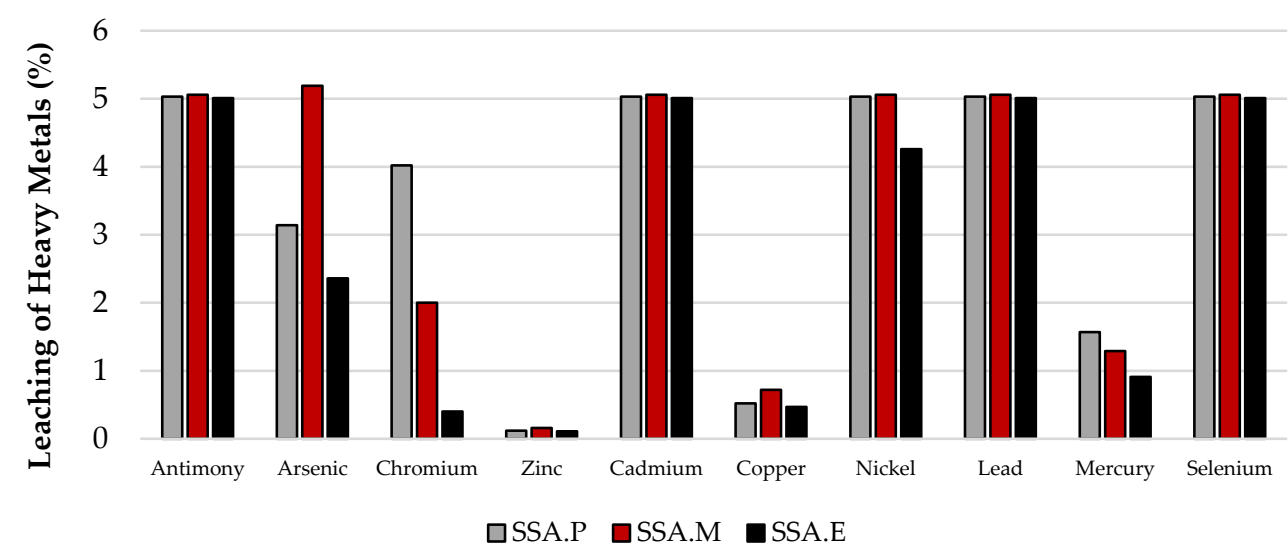

Figure 6. Leachability of heavy metals from mortars in relation to their total content.

Table 7. Ministerial criteria for waste and sewage discharged into the environment, surface water and potable water $(\mathrm{mg} / \mathrm{L})$.

\begin{tabular}{ccccccc}
\hline $\begin{array}{c}\text { Metal } \\
\text { (Symbol) }\end{array}$ & $\begin{array}{c}\text { Inert } \\
\text { Waste } \\
{[42]}\end{array}$ & $\begin{array}{c}\text { Non-Inert } \\
\text { Waste. } \\
\text { Adapted } \\
\text { from Ref. } \\
{[42]}\end{array}$ & $\begin{array}{c}\text { Hazardous } \\
\text { Waste. } \\
\text { Adapted } \\
\text { from Ref. } \\
{[42]}\end{array}$ & $\begin{array}{c}\text { Waste } \\
\text { Water. } \\
\text { Adapted } \\
\text { from Ref. } \\
{[43]}\end{array}$ & $\begin{array}{c}\text { Water Over } \\
\text { Cat. A3. } \\
\text { Adapted } \\
\text { from Ref. } \\
{[44]}\end{array}$ & $\begin{array}{c}\text { Potable } \\
\text { Water. } \\
\text { Adapted } \\
\text { from Ref. } \\
{[45]}\end{array}$ \\
\hline $\mathrm{Sb}$ & $<0.06$ & $<0.7$ & $<5$ & $<0.3$ & - & $<0.005$ \\
$\mathrm{As}$ & $<0.5$ & $<2$ & $<25$ & $<0.1$ & $<0.05$ & $<0.01$ \\
$\mathrm{Cr}$ & $<0.5$ & $<10$ & $<70$ & $<0.5$ & $<0.05$ & $<0.05$ \\
$\mathrm{Zn}$ & $<4$ & $<50$ & $<200$ & $<2$ & $<5$ & - \\
$\mathrm{Cd}$ & $<0.04$ & $<1$ & $<5$ & $<0.2$ & $<0.005$ & $<0.005$ \\
$\mathrm{Cu}$ & $<2$ & $<50$ & $<100$ & $<0.5$ & $<0.5$ & $<2$ \\
$\mathrm{Ni}$ & $<0.4$ & $<10$ & $<40$ & $<0.5$ & $<0.2$ & $<0.02$ \\
$\mathrm{~Pb}$ & $<0.5$ & $<10$ & $<50$ & $<0.5$ & $<0.05$ & $<0.01$ \\
$\mathrm{Hg}$ & $<0.01$ & $<0.2$ & $<2$ & $<0.03$ & $<0.001$ & $<0.001$ \\
$\mathrm{Se}$ & $<0.1$ & $<0.5$ & $<7$ & $<1$ & $<0.01$ & $<0.01$ \\
\hline
\end{tabular}




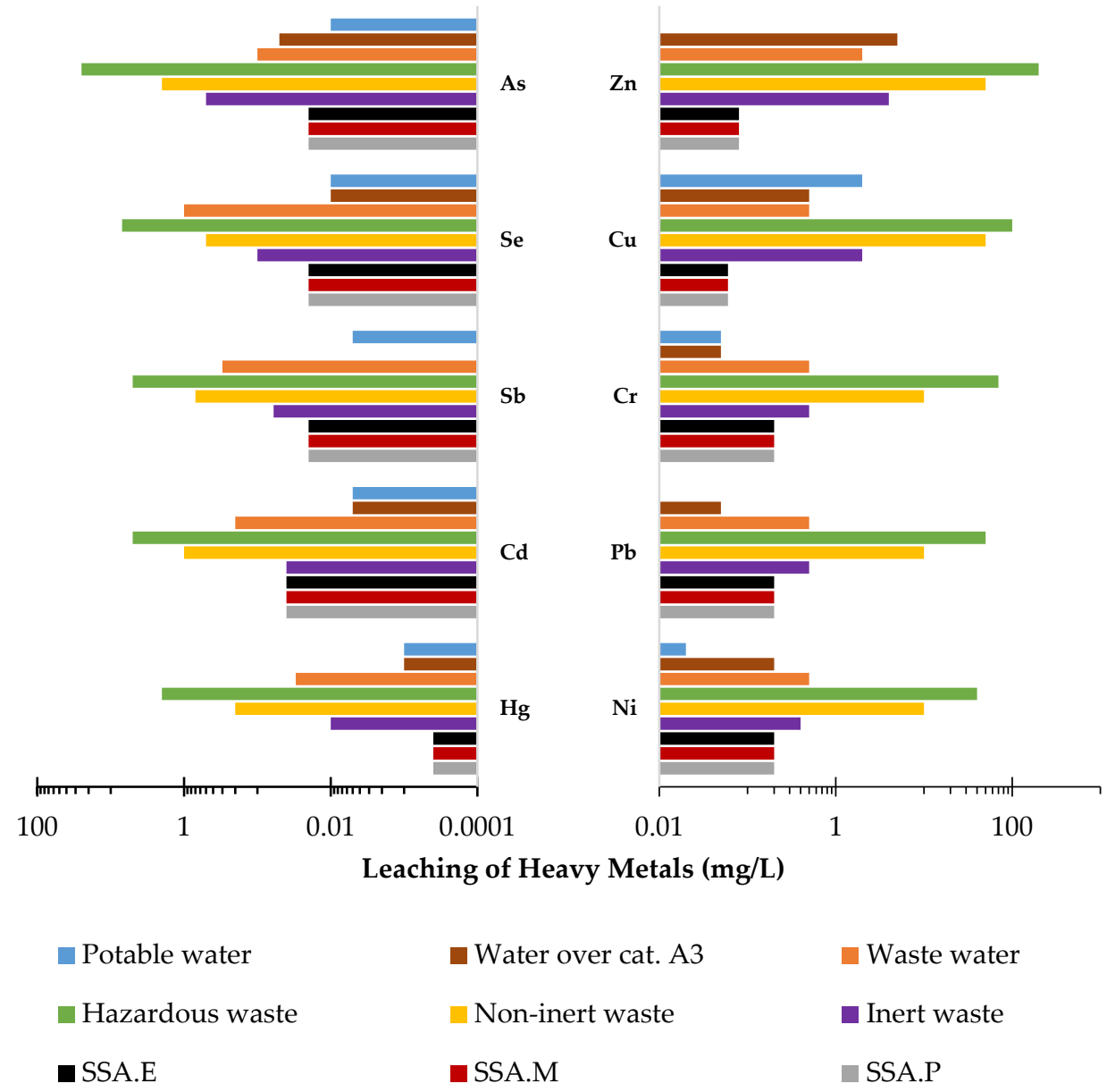

Figure 7. Leachability of heavy metals from mortars in relation to ministerial criteria for waste and sewage discharged into the environment, surface water, and potable water $(\mathrm{mg} / \mathrm{L})$.

\section{Conclusions}

This study has proposed sewage sludge ash heavy metals immobilisation in $\mathrm{CO}_{2}-$ cured mortars based on Portland cement, reactive magnesia, or electric arc furnace slag. Therefore, the results of this study are summarised below:

- The accelerated carbonation curing period led to a reduction of $\mathrm{CO}_{2}$-cured mortars bulk density at about $5 \%$.

- The compressive strength results achieved reached up to $12.7 \mathrm{MPa}$. Due to the high carbonation ability of $\mathrm{CaO}$ and $\mathrm{MgO}$, the quantity of these compounds seems to be directly related to the strength development in the $\mathrm{CO}_{2}$-cured mortars. Although SSA.E specimens presented the lowest compressive strength, they are nevertheless promising since the paste in this mortar composition is produced only from waste materials (sewage sludge ash and electric arc furnace slag).

- $\quad$ The TG-DTG and FT-IR analyses indicated that the carbonation reached the inner parts of these forming carbonate products, such as calcium carbonates $\left(\mathrm{CaCO}_{3}\right)$ and hydrated magnesium carbonates (HMCs), which are mainly responsible for the binding properties of the $\mathrm{CO}_{2}$-cured mortar compositions devised.

- The observed $\mathrm{CO}_{2}$-cured mortars' heavy metals leachability was at a very good level, generally not exceeding $5 \%$. Moreover, although the low compressive strength results observed in SSA.E mortar, it presented the highest heavy metal immobilisation degree among the three designed mortars, especially regarding arsenic, chromium, copper, nickel, and mercury. Finally, the criteria for inert waste and post-industrial wastewater according to Polish ministerial regulations, based on European Commission directives was met. 
Therefore, the $\mathrm{CO}_{2}$-cured mortars may be considered a promising cementitious material for immobilising heavy metals in which the compressive strength is related to the success in the accelerated carbonation curing process. Furthermore, this may represent an alternative way of making hybrid binders incorporating SSA and a reactive compound. Finally, the mortars produced may represent an effective way of not only incorporating SSA, but also a wide variety of wastes, and at the same time, capturing and storing $\mathrm{CO}_{2}$ in cementitious materials. However, future studies on the microstructure field are needed for a better understanding of the products developed in these composites.

Author Contributions: Supervision, J.C.-G., T.Z. and I.H.; writing-original draft, E.G.S.; writingreview and editing, E.G.S., J.C.-G., M.S., T.Z. and I.H. All authors have read and agreed to the published version of the manuscript.

Funding: This work was partially financed by Portuguese national funds through FCT - Foundation for Science and Technology, IP, within the research unit C-MADE, Centre of Materials and Building Technologies (CIVE-Central Covilhã-4082), University of Beira Interior, Portugal. This work has been financed by Polish National Agency for Academic Exchange under the International Academic Partnership Programme within the framework of the grant: E-mobility and sustainable materials and technologies EMMAT(PPI/APM/2018/1/00027). The research presented in this article was carried out in collaboration with Cracow University of Technology and Cracow Waterworks in Poland as a part of the POIR.04.01.02-00-0032/17 project financed by The National Centre for Research and Development.

Institutional Review Board Statement: Not applicable.

Informed Consent Statement: Not applicable.

Data Availability Statement: Not applicable.

Acknowledgments: We acknowledge Luís Calado and Roberta Panizio from Instituto Politécnico de Portalegre for carrying out the FTIR analyses.

Conflicts of Interest: The authors declare no conflict of interest.

\section{References}

1. Walling, S.A.; Provis, J.L. Magnesia-based cements: A journey of 150 years, and cements for the future? Chem. Rev. 2016, 116, 4170-4204. [CrossRef] [PubMed]

2. International Energy Agency. Technology Roadmap: Low-Carbon Transition in the Cement Industry; OECD/IEA: Paris, France, 2018; pp. 1-66. [CrossRef]

3. Gartner, E.; Sui, T. Alternative cement clinkers. Cem. Concr. Res. 2018, 114, 27-39. [CrossRef]

4. Shi, C.; Qu, B.; Provis, J.L. Recent progress in low-carbon binders. Cem. Concr. Res. 2019, 122, 227-250. [CrossRef]

5. Huntzinger, D.N.; Gierke, J.S.; Kawatra, S.K.; Eisele, T.C.; Sutter, L.L. Carbon dioxide sequestration in cement kiln dust through mineral carbonation. Environ. Sci. Technol. 2009, 43, 1986-1992. [CrossRef] [PubMed]

6. Humbert, P.S.; Castro-Gomes, J.P.; Savastano, H. Clinker-free $\mathrm{CO}_{2}$ cured steel slag based binder: Optimal conditions and potential applications. Constr. Build. Mater. 2019, 210, 413-421. [CrossRef]

7. Ruan, S.; Unluer, C. Influence of mix design on the carbonation, mechanical properties and microstructure of reactive $\mathrm{MgO}$ cement-based concrete. Cem. Concr. Compos. 2017, 80, 104-114. [CrossRef]

8. Unluer, C.; Al-Tabbaa, A. The role of brucite, ground granulated blastfurnace slag, and magnesium silicates in the carbonation and performance of $\mathrm{MgO}$ cements. Constr. Build. Mater. 2015, 94, 629-643. [CrossRef]

9. Unluer, C.; Al-Tabbaa, A. Enhancing the carbonation of $\mathrm{MgO}$ cement porous blocks through improved curing conditions. Cem. Concr. Res. 2014, 59, 55-65. [CrossRef]

10. Vandeperre, L.J.; Al-Tabbaa, A. Accelerated carbonation of reactive MgO cements. Adv. Cem. Res. 2007, 19, 67-79. [CrossRef]

11. Grünhäuser Soares, E.; Castro-Gomes, J. Preliminary study on the influence of different carbonation curing processes on binders based on magnesium oxide-rich powder blended with tungsten mining waste mud. KnE Eng. 2020, 2020, 215-227. [CrossRef]

12. Grünhäuser Soares, E.; Castro-Gomes, J. Early age compressive strength of waste-based-glass-powder magnesium silicate binders on initial carbonation curing. KnE Eng. 2020, 61-73. [CrossRef]

13. Grünhäuser Soares, E.; Castro-Gomes, J. Carbonation curing influencing factors of Carbonated Reactive Magnesia Cements (CRMC)—A review. J. Clean. Prod. 2021, 305, 127210. [CrossRef]

14. Cyr, M.; Coutand, M.; Clastres, P. Technological and environmental behavior of sewage sludge ash (SSA) in cement-based materials. Cem. Concr. Res. 2007, 37, 1278-1289. [CrossRef] 
15. Cheeseman, C.R.; Virdi, G.S. Properties and microstructure of lightweight aggregate produced from sintered sewage sludge ash. Resour. Conserv. Recycl. 2005, 45, 18-30. [CrossRef]

16. Ottosen, L.M.; Jensen, P.E.; Kirkelund, G.M. Electrodialytic separation of phosphorus and heavy metals from two types of sewage sludge ash. Sep. Sci. Technol. 2014, 49, 1910-1920. [CrossRef]

17. Fraissler, G.; Jöller, M.; Mattenberger, H.; Brunner, T.; Obernberger, I. Thermodynamic equilibrium calculations concerning the removal of heavy metals from sewage sludge ash by chlorination. Chem. Eng. Process. Process. Intensif. 2009, 48, 152-164. [CrossRef]

18. Giergiczny, Z.; Król, A. Immobilization of heavy metals ( $\mathrm{Pb}, \mathrm{Cu}, \mathrm{Cr}, \mathrm{Zn}, \mathrm{Cd}, \mathrm{Mn})$ in the mineral additions containing concrete composites. J. Hazard. Mater. 2008, 160, 247-255. [CrossRef]

19. Chen, Q.Y.; Tyrer, M.; Hills, C.D.; Yang, X.M.; Carey, P. Immobilisation of heavy metal in cement-based solidification/stabilisation: A review. Waste Manag. 2009, 29, 390-403. [CrossRef]

20. Sitarz, M.; Zdeb, T.; Castro Gomes, J.; Grünhäuser Soares, E.; Hager, I. The immobilisation of heavy metals from sewage sludge ash in geopolymer mortars. MATEC Web Conf. 2020, 322, 01026. [CrossRef]

21. PN-EN 12457-4:2006; Characterisation of Waste_Leaching-Compliance Test for Leaching of Granular Waste Materials and Sludges-Part 4: One Stage BATCH Test at a Liquid to Solid Ratio of $10 \mathrm{~L} / \mathrm{kg}$ for Materials with Particle Size below $10 \mathrm{~mm}$ (without or with Size Reduction); European Committee for Standardization: Brussels, Belgium, 2006.

22. EN 13346:2001; Characterization of Sludge_Determination of Trace Elements and Phosphorus—Aqua Regia Extraction Methods; European Committee for Standardization: Brussels, Belgium, 2001.

23. ISO 11885:2007; Water Quality. Determination of Selected Elements by Inductively Coupled Plasma Optical Emission Spectrometry (ICP-OES); European Committee for Standardization: Brussels, Belgium, 2007.

24. ISO 9174:1998; Water Quality-Determination of Chromium-Atomic Absorption Spectrometric Methods; European Committee for Standardization: Brussels, Belgium, 1998.

25. ISO 8288:1986; Water Quality. Determination of Cobalt, Nickel, Copper, Zinc, Cadmium and Lead_Flame Atomic Absorption Spectrometric Methods; European Committee for Standardization: Brussels, Belgium, 1986.

26. Al Naimi, K.M.; Delclos, T.; Calvet, N. Industrial waste produced in the uae, valuable high-temperature materials for thermal energy storage applications. Energy Procedia 2015, 75, 2087-2092. [CrossRef]

27. Costa, T.C.; Vazzoler, A.; de Araújo, W.P.; Gomes, E.A. Estimation of kinetic parameters during the treatment of steelmaking slag expansibility data. Mater. Res. 2018, 21, e20170665. [CrossRef]

28. Mota, R.M.; Silva, A.S.; Ramos, V.H.S.; Rezende, J.C.T.; de Jesus, E. Effects of storage temperature and time on false setting behavior of CPI-S Portland cement. Ceramica 2020, 66, 321-329. [CrossRef]

29. Dweck, J.; Buchler, P.M.; Coelho, A.C.V.; Cartledge, F.K. Hydration of a Portland cement blended with calcium carbonate. Thermochim. Acta 2000, 346, 105-113. [CrossRef]

30. He, Z.; Li, Z.; Shao, Y. Effect of carbonation mixing on $\mathrm{CO}_{2}$ uptake and strength gain in concrete. J. Mater. Civ. Eng. 2017, 29, 04017176. [CrossRef]

31. Gabrovšek, R.; Vuk, T.; Kaučič, V. Evaluation of the hydration of Portland cement containing various carbonates by means of thermal analysis. Acta Chim. Slov. 2006, 53, 159-165.

32. Lago, F.R.; Gonçalves, J.P.; Dweck, J.; Da Cunha, A.L.C. Evaluation of influence of salt in the cement hydration to oil wells. Mater. Res. 2017, 20, 743-747. [CrossRef]

33. Mo, L.; Zhang, F.; Deng, M. Mechanical performance and microstructure of the calcium carbonate binders produced by carbonating steel slag paste under $\mathrm{CO}_{2}$ curing. Cem. Concr. Res. 2016, 88, 217-226. [CrossRef]

34. Ren, H.; Chen, Z.; Wu, Y.; Yang, M.; Chen, J.; Hu, H.; Liu, J. Thermal characterization and kinetic analysis of nesquehonite, hydromagnesite, and brucite, using TG-DTG and DSC techniques. J. Therm. Anal. Calorim. 2014, 115, 1949-1960. [CrossRef]

35. Jin, F.; Al-Tabbaa, A. Thermogravimetric study on the hydration of reactive magnesia and silica mixture at room temperature. Thermochim. Acta 2013, 566, 162-168. [CrossRef]

36. Dung, N.T.; Lesimple, A.; Hay, R.; Celik, K.; Unluer, C. Formation of carbonate phases and their effect on the performance of reactive $\mathrm{MgO}$ cement formulations. Cem. Concr. Res. 2019, 125, 105894. [CrossRef]

37. Soriano, L.; Tashima, M.M.; Bonilla, M.; Payá, J.; Monzó, J.; Borrachero, M.V. Use of high-resolution thermogravimetric analysis (HRTG) technique in spent FCC catalyst/Portland cement pastes. J. Therm. Anal. Calorim. 2015, 120, 1511-1517. [CrossRef]

38. Castro-Gomes, J. Methematical Models for Assessing Hydration and Microstructure of Cement Pastes; University of Leeds: Leeds, UK, 1997.

39. Bhagath Singh, G.V.P.; Sonat, C.; Yang, E.H.; Unluer, C. Performance of $\mathrm{MgO}$ and $\mathrm{MgO}-\mathrm{SiO}_{2}$ systems containing seeds under different curing conditions. Cem. Concr. Compos. 2020, 108, 103543. [CrossRef]

40. Abdel-Gawwad, H.A.; Hassan, H.S.; Vásquez-García, S.R.; Israde-Alcántara, I.; Ding, Y.C.; Martinez-Cinco, M.A.; Abd ElAleem, S.; Khater, H.M.; Tawfik, T.A.; El-Kattan, I.M. Towards a clean environment: The potential application of eco-friendly magnesia-silicate cement in $\mathrm{CO}_{2}$ sequestration. J. Clean. Prod. 2020, 252, 119875. [CrossRef]

41. Botha, A.; Strydom, C.A. DTA and FT-IR analysis of the rehydration of basic magnesium carbonate. J. Therm. Anal. Calorim. 2003, 71, 987-996. [CrossRef]

42. Journal of Laws of the Republic of Poland Item 1277/1.09.2015. Available online: http:/ /isap.sejm.gov.pl/isap.nsf/DocDetails. xsp?id=WDU20150001277 (accessed on 11 February 2021). 
43. Journal of Laws of the Republic of Poland Item $984 \mathrm{n}^{\circ}$. 137/2006 KM 1. Available online: http://isap.sejm.gov.pl/isap.nsf/ download.xsp/WDU20061370984/O/D20060984.pdf (accessed on 11 February 2021).

44. Journal of Laws of the Republic of Poland Item 1747/29.08.2019. Available online: https://isap.sejm.gov.pl/isap.nsf/download. xsp/WDU20190001747/O/D20191747.pdf (accessed on 11 February 2021).

45. Journal of Laws of the Republic of Poland Item 2294/7.12.2017. Available online: http:/ /isap.sejm.gov.pl/isap.nsf/DocDetails. xsp?id=WDU20170002294 (accessed on 10 February 2021). 